\title{
As viagens da favela e a vida social dos suvenires
}

Bianca Freire-Medeiros

\& Palloma Valle Menezes*

Resumo: Este artigo resgata e examina a biografia da favela turística a partir de sua cultura material. Suvenires produzidos e comercializados em duas favelas cariocas (Rocinha e Santa Marta) constituem o ponto de observação privilegiado para o entendimento das espirais de sentido que se erguem na confluência entre imaginação e materialidade, arte e topografia. Partimos das cores que nascem nas telas pintadas para consumo dos turistas e se reproduzem nas paredes das favelas, tomando-as fruto de políticas baseadas em novos regimes de visibilidade e controle da pobreza. As considerações finais refletem sobre a morte dos (anti)suvenires ou o que parece ser um esgotamento das possibilidades de representação da favela como marca capaz de agregar valor a diferentes produtos no mercado global.

Palavras-chave: suvenir, favela, turismo, cultura material, megaeventos.

\section{Introdução}

N

ão há registro oficial que defina com precisão o início dos passeios pagos pelas favelas cariocas, mas vários relatos convergem para um evento comum: a conferência internacional 1992 Earth Summit ou, como ficou conhecido entre nós, a Eco-92 (Freire-Medeiros, 2009; 2013; Frenzel, 2016). Ao congregar mais de 30 mil visitantes, incluindo cerca de 100 chefes de estado e 10 mil jornalistas, o evento era a oportunidade de redesenharmos a imagem, então desabonada pela sucessão de episódios de violência que ocupavam o noticiário internacional, do Rio de Janeiro como destino turístico. Diante da missão de reverter as estatísticas negativas - dados da Embratur atestam que em 1991 haviam chegado ao Rio de Janeiro pouco mais de 400 mil estrangeiros, ou seja, metade do número contabilizado em 1988 (ver Teixeira, 2015) -, os esforços institucionais voltavam-se sobretudo para que fosse garantida uma atmosfera de ordem e segurança. A população de rua foi removida das áreas turísticas e as favelas aí localizadas foram camufladas por tanques de guerra e soldados em verde musgo.

Para desilusão dos agentes públicos, esses elementos de uma cenografia da exclusão acabaram por atrair o olhar curioso dos visitantes. Agências de notícias nacionais e estrangeiras passaram não apenas a acusar o governo brasileiro de maquiar a cidade para o evento, mas também a incentivar que os bastidores viessem à cena.

\author{
* Bianca Freire- \\ Medeiros é \\ professora do \\ Departamento e \\ do Programa de \\ Pós-Graduação \\ em Sociologia da \\ Universidade de São \\ Paulo, coordenadora \\ do UrbanData- \\ Brasil e Tinker \\ Visiting Professor \\ na Universidade do \\ Texas em Austin. \\ <freiremed@hotmail. \\ com $>$. \\ Palloma Valle \\ Menezes é doutora \\ em sociologia \\ pela Universidade \\ do Estado do Rio \\ de Janeiro e pela \\ Vrije Universiteit, \\ Amsterdam. \\ Atualmente é \\ pós-doutoranda do \\ Centro de Pesquisa \\ e Documentação \\ de História \\ Contemporânea do \\ Brasil da Fundação \\ Getulio Vargas \\ (CPDOC/FGV). \\ <pallomamenezes@
} gmail.com>. 
Lideranças de diversos movimentos sociais brasileiros e de organizações internacionais - como o Greenpeace - decidiram organizar uma visita à Rocinha, território encravado entre dois bairros de altíssimo poder aquisitivo na prestigiosa Zona Sul carioca. Aquela que viria a se tornar nosso paradigma de favela turística recebeu delegados do evento, militantes de ONGs e cerca de 200 jornalistas na intenção de revelar as condições precárias em que os residentes se viam submetidos e que desmentiam o discurso oficial que propagava uma cidade quase onírica em sua combinação singular entre beleza natural e cordialidade humana. Alguns operadores de turismo viram ali uma oportunidade para promover um novo destino que, pouco a pouco, foi deixando as margens dos roteiros turísticos para se tornar completamente integrado à imagem da cidade. Atualmente, há uma diversidade de "favela tours" à disposição dos interessados em conhecer o que o mercado turístico chama de "o verdadeiro Rio de Janeiro", assim como são evidentes a ampliação do leque de equipamentos turísticos (albergues, restaurantes, lojas de suvenires etc.) e o crescente engajamento dos próprios favelados no desenvolvimento de atividades turísticas em seus locais de moradia (Moraes, no prelo).

Não seria exagero dizer, portanto, que a favela turística se favoreceu na origem da mobilidade transcontinental de pessoas e ideias, de imagens e informações que, durante grandes eventos como a Eco-92, ganha magnitude potencializada. Porém, para que fosse possível ultrapassar a condição episódica e consolidá-la na rotina do mercado da pobreza turística, que àquela época começava a despontar em diversas localidades do Sul Global (ver Freire-Medeiros, 2009; 2013; Frenzel, Koens \& Steinbricnk, 2012), os promotores do turismo em favela precisaram garantir também o trânsito de objetos sem os quais os destinos de viagem dificilmente vingam: os suvenires. É dessas "coisas" que funcionam como marcadores tangíveis de uma experiência cultural peculiar - aquela que envolve a conversão da experiência da pobreza em mercadoria turística - que trata este artigo. Nossa hipótese geral é que os suvenires produzidos no contexto da favela turística oferecem um ponto de observação privilegiado de onde podemos compreender os paradoxos dos fluxos transnacionais que se dirigem a determinadas favelas e que de lá se projetam nas mais diversas direções.

\section{As "coisas" da favela turística}

O estudo da cultura material, dos objetos e sua materialidade, das condições de produção e consumo, há muito frequenta os espaços institucionais e as iniciativas editoriais de várias disciplinas. É fato, porém, que esses temas adquiriram maior relevância e passaram a ser vistos sob outra ótica teórica a partir da publicação, em 1986, da coletânea The social life of things, organizada por Arjun Appadurai. Em contraposição à ideia de que as coisas possuem um valor intrínseco e mensurável, 
Georg Simmel defendia que o valor é sempre contingente e relativo, no tempo e no espaço. Appadurai retoma essa linha de pensamento, estendendo-a em direção ao estudo dos movimentos históricos dos objetos, das contingências sociais e políticas que conformam suas biografias culturais. Se antes o foco se dirigia às formas e funções da troca, no contexto dos estudos da cultura material pós-1980 é o elemento "trocado" que ganha centralidade.

De maneira geral, o estudo dos suvenires é revelador das relações entre cultura material, representações sociais, estratégias de mercado e práticas de consumo presentes no contexto de uma experiência social - o turismo -, cuja existência remete, desde a origem, a trânsitos transcontinentais (Urry, 2001; 2007). Historiadores, antropólogos, sociólogos, entre outros, têm explorado de maneira produtiva o papel cumprido pelos suvenires como objetos da memória (Swanson, 2004) e como signos condensadores da experiência de viagem (Gordon, 1986), bem como a importância crucial por eles exercida nas relações de reciprocidade tão caras aos viajantes contemporâneos (Kim \& Littrell, 2001; Ward \& Tran, 2007).

No caso específico da favela turística, o exame dessas "coisas" possibilita, por um lado, recuperar a própria trajetória do que uma de nós chamou de "traveling favela" (Freire-Medeiros, 2013) e, por outro, examinar a relação de espelhamento entre a favela como território da imaginação e as transformações na materialidade empírica das diferentes favelas turísticas. A noção de "traveling favela", ao privilegiar a mobilidade da e na favela, busca elucidar como sua transformação em destino turístico e em marca está longe de ser um processo inequívoco, ao contrário, trata-se de um processo complexo e contraditório, no qual a pobreza adquire um valor de troca no mercado globalizado de forma imprevisível e enigmática. Não é de se estranhar que os suvenires, como um dos suportes materiais que garantem a circulação contínua da favela como trademark, ao mesmo tempo em que se beneficiam de sua perpetuação como destino turístico, estejam mergulhados em lógicas conflitantes que escapam à previsibilidade interpretativa.

De onde vêm os suvenires que tornam tangível e colecionável a experiência da favela turística? Qual será o seu percurso e quais as motivações para que se ponham em circulação? O que essas "coisas" significam, para quem e por quê? Como se dá, na produção desses suvenires, a dialética entre e massificação e singularização, entre o local e o global, tão própria da experiência turística contemporânea?

Procuramos responder a esse conjunto de questões voltando-nos para reflexões acumuladas ao longo da última década. Em 2006, no contexto do projeto de pesquisa "Para ver os pobres: a favela como destino turístico"1 realizamos observação participante nos três pontos de venda de suvenires existentes à época na Roci-
1. Financiado pelo Conselho Nacional de Desenvolvimento Científico e Tecnológico (CNPq) e pela Foundation for Urban and Regional Studies (Furs), o projeto de pesquisa examinou o processo de elaboração, venda e consumo da favela como atração turística. Ver FreireMedeiros, 2007; 2009; 2013. 
2. O projeto "Turismo em comunidades pacificadas" foi coordenado por Bianca FreireMedeiros e Marcio Vilarouca. Foram realizadas 40 entrevistas qualitativas com atores envolvidos nas atividades turísticas ou por elas afetados diretamente (moradores, guias locais, comerciantes, agências de turismo e staff da UPP) e dois surveys: 400 questionários com turistas estrangeiros e 900 com turistas nacionais e estrangeiros (este último aplicado no Aeroporto Internacional Antônio Carlos Jobim). Para conhecer os resultados, ver Freire-Medeiros et alii (2012; 2013) e Freire-Medeiros e Vilarouca (2015).

3. Para um exame detido das práticas de consumo dos turistas na Rocinha e no Santa Marta, ver, respectivamente, Freire-Medeiros, Menezes e Nunes (2008) e FreireMedeiros e Vilarouca (2015).

4. No contexto dos megaeventos que nos últimos anos vêm tomando o Rio de Janeiro como palco, outras favelas - Morro da Babilônia, Vidigal, Complexo do Alemão, para citarmos algumas - têm sido incorporadas aos roteiros turísticos da cidade por iniciativa de atores privados nha. Foram conduzidas ainda entrevistas com donos de operadoras de turismo e guias, produtores e vendedores de suvenires, moradores e turistas, na tentativa de apreender como se dava a produção e o consumo dos objetos que compunham a experiência da Rocinha turística. Em 2011, direcionamos nossos esforços de pesquisa para a favela Santa Marta, onde passeios guiados começavam a se tornar rotina. Ainda que naquele momento o volume de suvenires produzidos e comercializados ali fosse modesto, procuramos contemplar em profundidade o tema nas entrevistas que realizamos com artesãos, guias de turismo e lideranças locais. Além disso, no âmbito da mesma pesquisa (patrocinada pelo Ministério do Turismo, em parceria com o FGV Opinião ${ }^{2}$ ), foram aplicados, junto a 400 turistas, questionários que incluíam uma seção própria sobre as práticas e expectativas de consumo durante o passeio. Em fins de 2015, quando o Santa Marta já se encontrava totalmente consolidado como destino turístico, voltamos a campo para entrevistar produtores e donos de lojas de suvenir, assim como realizar um mapeamento dos produtos por eles comercializados.

Note-se que, a despeito da abrangência de nossas pesquisas anteriores, a intenção aqui é bastante circunscrita: traçar a vida social dos "suvenires de favela", recobrando as espirais de representação e sentido que vão dos territórios empíricos aos objetos e vice-versa. Com esse objetivo em mente, conduzimos nosso argumento costurando duas linhas principais: por um lado, elegemos as telas em detrimento da vastidão de outros objetos que são comercializados como suvenires tanto na Rocinha (Nunes, 2010) quanto no Santa Marta; por outro, privilegiamos o ponto de vista dos artesãos e comerciantes em oposição àquele dos turistas, o que não significa, porém, que as demandas desse público estejam ausentes. Os consumidores, como se verá, são presença constante na fala dos artesãos e dos que comercializam os suvenires, operando ao mesmo tempo como fonte de inspiração criativa e de constrangimento prático ${ }^{3}$.

Na próxima sessão, trataremos dos intercâmbios, das transferências e das apropriações produzidos no contexto das favelas turísticas e apreensíveis a partir do exame cruzado de seus suvenires vis-à-vis sua topografia. Partiremos das cores que nascem nas telas pintadas por artistas da Rocinha e se reproduzem nas paredes coloridas das casas não apenas aí, mas também na "outra" favela turística: o Santa Marta4. Na seção subsequente, as especificidades da vida dos suvenires produzidos nesta que foi a primeira favela "pacificada" da cidade do Rio de Janeiro são por nós perseguidas na intenção de resgatar seus percursos contínuos entre imaginação e materialidade. As considerações finais buscam refletir, nesta retomada da biografia da favela turística a partir de sua cultura material, sobre a morte dos (anti)suvenires ou, dito de outro modo, o que parece ser um esgotamento das possibilidades de representação da favela como trademark. 


\section{"Façam aquarela da miséria colorida"}

Rocinha, verão de 2007. Em uma das principais vias da favela, onde ocorre a primeira parada da maioria das agências de turismo, artesãos expõem e comercializam produtos variados: bolsas e cintos de anel de alumínio; imãs e minimaquetes feitas com caixas de remédio, de fósforo e com fios de telefone; bolsas e chapéus de sacolas plásticas. Enquanto os grupos de turistas ouvem as explicações do guia de turismo e fotografam a vista deslumbrante do Cristo Redentor e da Lagoa Rodrigo de Freitas, Maicon encena a pintura de um de seus muitos quadros (Figura 1). De proporções maiores do que as outras ali expostas (os artistas sabem que o turista costuma dar preferência a pequenos quadros que sejam mais fáceis de transportar, como os expostos do lado direito da foto), a tela chama a atenção dos "gringos" e das pesquisadoras ${ }^{5}$. Não que sua temática seja inédita - afinal, multiplicam-se as pinturas que retratam o casario da favela, tema também largamente privilegiado pelas câmeras dos turistas (ver Menezes,

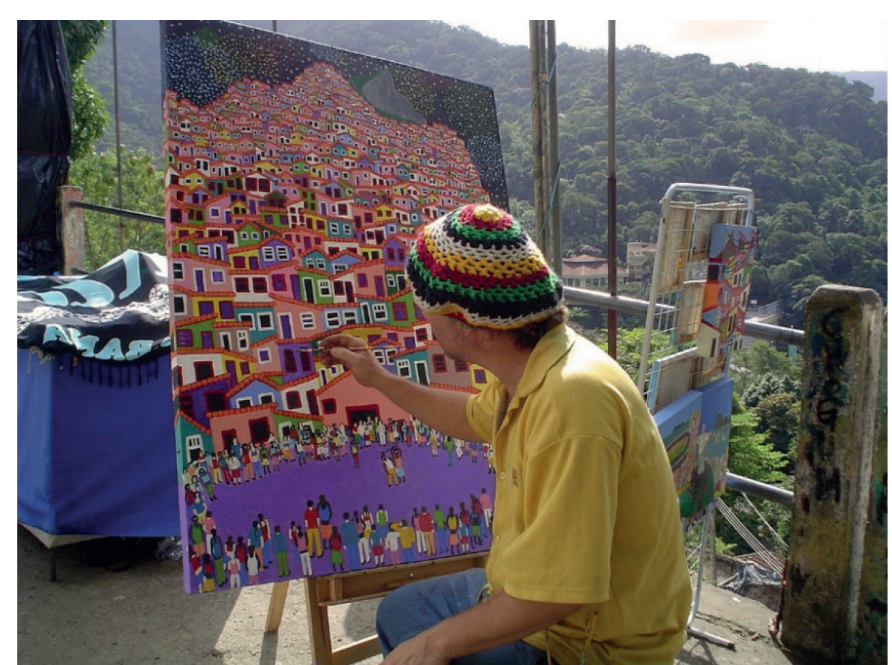

Figura 1: Morador da Rocinha encena a pintura do quadro para atrair atenção dos turistas que passam pela Rua 1. Fonte: Fernanda Nunes.

2007; Freire-Medeiros, Menezes \& Nunes, 2008), mas a composição feita entre a massa de casinhas coloridas, o céu estrelado e a cena da roda de moradores sobre o solo tingido de roxo consegue capturar nosso olhar.

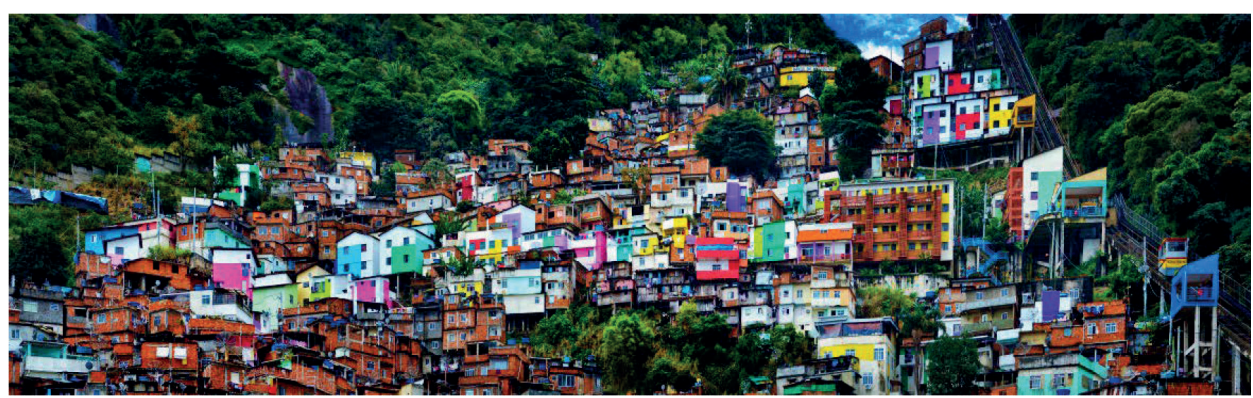

Figura 2: Fotografia panorâmica do Morro Santa Marta, em 2014. Fonte: <http://sala7design.com.br/2014/11/ projeto-tudo-de-cor-pra-voce-leva-cor-e-arte-para-favela-santa-marta-rj.html>. Acessado em abril de 2016.

e/ou públicos. Foi no Santa Marta, porém, que o volume de passeios pagos tornouse comparável àquele da Rocinha: atualmente, ambas recebem uma média de quatro mil turistas por mês.

5. No verão de 2006, as autoras, acompanhadas das assistentes de pesquisa Fernanda Nunes e Lívia Campello, fizeram intenso trabalho de campo para observar as relações entre guias de turismo, turistas, vendedores e produtores de suvenires que se concentravam especialmente na Rua 1. Agradecemos a ambas pela dedicação e parceria. 
"Comecei pintando barraquinhos coloridos, acho que lembrando da Rocinha da minha infância", recorda Maicon. "Mas aí eu olhei em volta e vi que já não tinha quase barraco na Rocinha, o que tinha era prédio alto, de dois e três andares. Parei de pintar barraquinho e passei a pintar os prédios". De fato, na paisagem daquela que é comercializada no mercado turístico como "a maior favela do Brasil", salta aos olhos e impressiona a quantidade de prédios com ou sem reboco cujas lajes em construção denunciam o intento de seguir subindo. Como explicar então que sejam as modestas casinhas de madeira em múltiplas cores a habitar os suvenires em exposição? "Tentei pintar os prédios, mas não funcionou. Não vendi nada. O turista quer mesmo é barraquinho colorido", conclui Maicon.

Sete anos depois, outra foto nos leva da Rocinha para o Santa Marta (Figura 2). Os tons de roxo, rosa, amarelo, azul e verde parecem ter saltado da tela de Maicon para as paredes da primeira favela "pacificada". A tipologia das construções, a proximidade entre as residências, a falta de ruas e até a forma como as casas são pintadas, com molduras brancas delimitando os tons coloridos, assemelham-se muito nas duas imagens. A diferença entre a paisagem e a pintura é menos de qualidade do que de quantidade: a existência de um grande número de casas ainda por pintar no Santa Marta passa a impressão de que a paisagem da favela é uma réplica ainda inacabada ou um esboço em construção da obra do pintor da Rocinha.

Examinemos com atenção o que a fotografia revela e a história recente do Santa Marta informa. Do lado esquerdo, vemos um grande muro de concreto que foi erguido em 2009 pelo governo do estado com a justificativa, contestada pelos moradores, de que era preciso conter o crescimento da favela em direção à mata; do lado direito, o plano inclinado, inaugurado no início de 2008, que conta com cinco estações e garante o incremento da mobilidade nesta que é a favela carioca mais íngreme; entre esses dois marcos, prédios de vários andares que testemunham o processo de verticalização que vem ocorrendo no Santa Marta, desde o princípio dos anos 2000. Por fim, nosso olhar se fixa no quarto elemento - a presença de edificações pintadas com cores variadas e chamativas que fogem do padrão monocromático típico das construções nas favelas - que, nesta narrativa da favela turística, exige reflexões adicionais.

6. Esta e as demais reportagens citadas nesta seção encontramse disponíveis no site: <http:// favelatemmemoria. com.br/bonita-porfora/>. Acessado em abril de 2016.
Em primeiro lugar, cabe registrar que a aposta no potencial da paleta de cores na construção da favela como destino turístico revela-se muito mais antiga do que se poderia a princípio supor: em 1959, Mário Saladini, então diretor de Turismo e Certames da Prefeitura, sugeriu que a pintura dos barracos em cores diversas haveria não apenas de melhorar "o aspecto estético e higiênico" das favelas, mas também de "Ihe atrair visitantes". Segundo matéria publicada no Diário Carioca, em 3 de outubro de 1959, sob o título "Favela vai mostrar 'miséria colorida'"6, aos favelados 
caberia a limpeza dos barracos que, em seguida, seriam fotografados e, a partir dessas imagens, artistas contratados pela prefeitura definiriam as cores adequadas. Se "o problema da habitação miserável" era, como argumentava Saladini, "universal" e intransponível na sua totalidade, cabia ao poder público "melhorar seu aspecto e até transformá-la numa atração turística".

O projeto do diretor de Turismo e Certames rendeu inúmeras reações públicas de apoio e crítica. A oposição mais contundente teria sido encabeçada pelo então arcebispo do Rio e criador da Cruzada São Sebastião, Dom Hélder Câmara. Mas é na revista $O$ Cruzeiro, de 31 daquele mês de outubro, onde encontramos a ponderação que melhor revela a dificuldade de acomodar a favela na narrativa de uma cidade cujo status de capital da República havia sido demovido, mas que lutava para se manter como a principal vitrine do país:

Todo o mundo sabe e deplora - as favelas são uma chaga social, uma vergonha, uma tragédia. Mas o diretor do Turismo não é culpado disso, nem tem autoridade para interferir no problema. Ele é unicamente uma espécie de maquilador da cidade... (O Cruzeiro, 31 Out. 1959).

Nas linhas seguintes, explicita-se a ansiedade provocada pelas aproximações semânticas entre turismo e pobreza, visibilidade e favela:

\begin{abstract}
Poder-se-á alegar então que cuidar de turismo num tempo em que todo mundo passa fome é uma futilidade. Mas isso são outros quinhentos mil-réis. Mesmo porque, turismo já não é mais brincadeira, é indústria, e por toda parte rende dólares aos milhões. O daqui não rende porque ainda não há; turismo houvesse, dando dinheiro, quem sabe se poderia com ele urbanizar as favelas? Embora eu duvide que, depois de apanhar o cobre, a turma fosse se lembrar de favelado. Diriam logo que era pitoresco, que as favelas são uma tradição da cidade... (O Cruzeiro, 31 Out. 1959).
\end{abstract}

A proposta também inspirou Jota Júnior e Oldemar Magalhães a compor a canção "Favela amarela". Em seus versos, fica mais uma vez evidente a dificuldade de se encontrar, naquele momento, um lugar de classificação - exceto o da ironia - para uma favela em cores e potencialmente turística: "Ironia da vida. Pintem a favela. Façam aquarela da miséria colorida". Como bem sabemos, o plano de Saladini não vingou, mas o samba garantiu à cantora Araci de Almeida o título de Rainha do Carnaval de 1960 e à posteridade o registro poético do episódio.

Em segundo lugar, se não constitui novidade a aposta no potencial turístico de uma favela colorida, é preciso reconhecer que uma conjuntura recente - o que a literatura convencionou chamar de "contexto dos megaeventos" - ofereceu as condições 


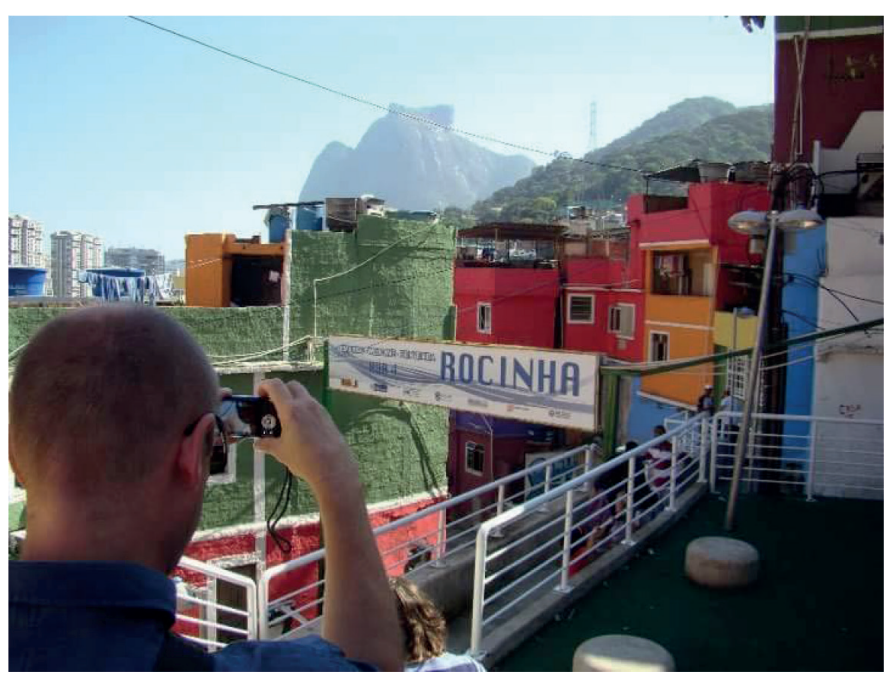

Figura 3: As edificações coloridas, que saíram das telas pintadas para o consumo dos gringos e invadiram a paisagem física da Rocinha, seguem capturando o olhar do turista. Fonte: Bianca Freire-Medeiros. de possibilidade para que viesse a adquirir legitimidade, e de fato se concretizar, aquilo que antes havia sido apenas delírio extravagante de um agente público ou fruto da imaginação artística. A "versão a cores" da Rocinha e do Santa Marta encaixa-se, portanto, em um conjunto maior de intervenções espetaculares que alvejaram sua paisagem física e a conduta de seus habitantes para adequá-los à narrativa mais ampla do Rio de Janeiro como "máquina de entretenimento" (Clarke, 2003). Tais intervenções, por certo, não se limitaram a esses dois territórios: como demonstram as análises de Cavalcanti (2013) e Leite (2015), as "grandes obras" - teleféricos, complexos esportivos, bibliotecas multifuncionais - levadas a cabo no contexto de pareamento UPPS/PAC-favelas modificaram a paisagem de diferentes partes da cidade. Elevam-se na confluência de interesses compartilhados por atores públicos e privados, agentes governamentais e mercados, e se fizeram valer mediante a repetição $a d$ nauseum de elementos retóricos - "inclusão produtiva", "empreendedorismo", "autoestima" - e forjaram a legitimação de um novo regime de visibilidade e de controle da pobreza. Nos casos da Rocinha e do Santa Marta, a esse repertório de ações e estratégias direcionadas para, evocando a expressão de Foucault (1991), "conduzir as condutas" nas favelas, somou-se a utilização férrea do turismo como prática cotidiana de sustentação (ver Freire-Medeiros, Vilarouca \& Menezes, 2016) do projeto mais amplo de reconfiguração da cidade.

Na biografia das duas favelas turísticas, o capítulo em cores começou a ser escrito em 2010. Na Rocinha (Figura 3), segundo o Ministério do Planejamento, foram gastos $\mathrm{R} \$ 278,8$ milhões (R\$156,5 milhões do governo federal e $\mathrm{R} \$ 122,3$ milhões do estado) com as obras do Plano de Aceleração do Crescimento (PAC) que incluíram, entre outros, um complexo esportivo, uma passarela projetada por Oscar Niemeyer, uma biblioteca comunitária, a urbanização e o alargamento de ruas e a criação de um conjunto de nove prédios com 144 apartamentos. Esses novos prédios, assim como uma série de casas localizada na entrada da Rocinha, foram pintados com cores vibrantes, formando um corredor colorido que conduz o fluxo turístico na favela. 
Já no caso do Santa Marta (Figura 4), até 2014 haviam sido pintadas algo como 450 edificações - número comparativamente maior do que na Rocinha - graças a uma parceria do governo do estado com a empresa de Tintas Coral. O então vice-governador e coordenador de Infraestrutura, Luiz Fernando Pezão, durante o lançamento do programa Tudo de

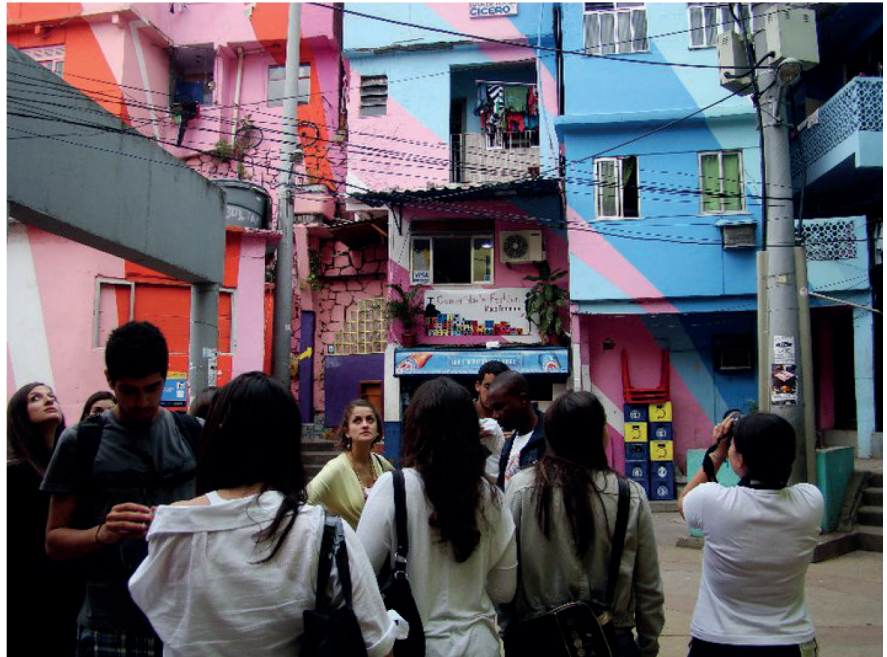

Figura 4: O colorido geométrico da Praça do Cantão, no Santa Marta, pretende singularizar a localidade ao mesmo tempo em que a encerra no cliché da favela turística e globalizada. Fonte: Bianca Freire-Medeiros.

Cor $^{7}$ para o Rio de Janeiro, em 29 de novembro de 2012, reforçou a importância da parceria no contexto de "pacificação" das favelas cariocas:

Entramos aqui para não sair mais e não saímos. Mas, se o poder público tem de entrar nessas comunidades, tem de entrar também a iniciativa privada, trazer bancos, lojas de material de construção, serviços. Quando o empresário acredita, a guerra está ganha. Por isso, quero agradecer muito a confiança da Coral em realizar esta parceria com o estado. É disso que a gente precisa.

Um exame mais detido desse alinhamento entre interesses públicos e privados, entre o governo do estado e uma fábrica de tintas de origem holandesa, revela não apenas o novo ordenamento que pretende despolitizar a cidade e regê-la a partir da lei do mercado (Telles, 2015), mas igualmente a vocação da favela turística para ser atravessada por mobilidades transnacionais de várias ordens. Seu marco inaugural - a chamada "laje do Michael Jackson" - celebra um Santa Marta há muito globalizado: ali estão a estátua do astro pop, de autoria do badalado escultor-cartunista Ique, e a reprodução de seu semblante em mural colorido assinado pelo "internacionalíssimo" Romero Britto, ambos evocando a memória da polêmica passagem de Jackson pelo morro, nos anos 1990. No processo de conversão estética da Praça do Cantão em atrativo turístico, repetem-se as mesmas estratégias de inserção da paisagem física da favela na narrativa mais ampla do "poor chic" (Halnon, 2002).

Não surpreende, assim, que tenham sido convocados dois artistas plásticos holandeses, Jeroen Koolhaas e Dre Urhahn, capazes de alçar a iniciativa às páginas internacionais. No bojo de seu prestigiado projeto "Favela Painting" 8 , os jovens, conhecidos

7. A Coral lançou em 2009 o programa "Tudo de cor para você no Brasil" com o objetivo de "levar bem-estar à vida das pessoas por meio das cores". Desde então, mais de dois mil imóveis foram pintados em comunidades de doze diferentes regiões do país, como São Paulo, Salvador, Florianópolis, Rio de Janeiro, Fortaleza, entre outras.

8. ver: <www favelapainting.com> 
9. Quando demos início ao nosso trabalho de campo na Rocinha, produtos industrializados quase não ganhavam espaço no comércio da Rua 1 , onde suvenires mais rústicos e feitos a partir de materiais reciclados eram vendidos em barraquinhas desmontáveis com estrutura de alumínio e cobertura de lona plástica. No Santa Marta, há lojas bem montadas onde são comercializados muitos objetos produzidos em série e que chegam à favela desde fornecedores de diferentes partes do Brasil. Uma entrevistada nos contou que vários desses produtos "são mais genéricos, mas alguns são de favela. Uma empresa de Santa Catarina, por exemplo, criou canecas e almofadas com estampa de casas coloridas e, como nós já temos essa questão da favela colorida, nós adquirimos para vender aqui". como Haas \& Hahn, redefiniram a Praça do Cantão a partir de uma intervenção de cores e padrões geométricos. "Cerca de sete mil metros quadrados de morro convertidos em um monumento para a comunidade", celebra o duo de artistas em seu website em que discursos sobre estética, cidadania e reforma social se entrelaçam e sobrepõem. Evocando noções há muito encharcadas de significado nas narrativas sobre a favela turística - inclusão social, orgulho, autoestima -, apostam na capacidade da intervenção artística de transformar o Santa Marta de favela em monumento.

Esse atravessamento da favela turística por idealizações e fluxos transnacionais é coerente com as dinâmicas próprias a uma entidade móvel e dessubstancializada como a "traveling favela" (Freire-Medeiros, 2010). Isso não quer dizer, porém, que essas negociações entre o global e o local, o genérico e o específico, que as cores do Santa Marta tão bem expressam, estejam ausentes de tensões, como veremos a seguir.

\section{Suvenires nas espirais de representação e cor}

Nos últimos anos, o Santa Marta viu multiplicar-se o número de turistas circulando pela favela. É também evidente o crescimento da quantidade de moradores que passaram a atuar no trade turístico local, quer como guias, quer como artesãos ou vendedores de suvenir. Na intenção de fortalecer essas iniciativas, foi aberta pela Investe Rio, agência de fomento do governo do estado, uma linha de crédito que ia de trezentos a seis mil reais por negócio, ao mesmo tempo em que o Serviço Brasileiro de Apoio às Micro e Pequenas Empresas (Sebrae) oferecia oficinas de empreendedorismo realizadas na própria favela. Em decorrência dessas várias iniciativas, diferentes produtos - chaveiros com o rosto de Michael Jackson, blusas, bonés, bolsas, canecas, almofadas, cadernetas com estampas da favela, postais e placas, entre ou$\operatorname{tros}^{9}$ - passaram a ser vendidos em lojas de suvenires espalhadas pelo morro.

A iconografia da favela presente nos suvenires, quando voltada à representação de sua paisagem física, é composta por um conjunto de residências muito semelhantes que aparecem coladas umas nas outras. A heterogeneidade das construções é praticamente ausente: quase não há variação no tipo de material de construção empregado, no estilo arquitetônico, nem no tamanho das casas. O único elemento que escapa a essa rotina redutora é justamente a cor da fachada: nas superfícies dos vários objetos a favela representada lembra um arco-íris.

Andreia Miranda, dona de uma das lojas de suvenir mais bem-sucedidas do morro, encontra explicação para a presença de uma favela tão repleta de cores na cultura material que conforma o Santa Marta turístico inserindo-a nas espirais de representação que vão da intenção estética do artista à paisagem física da favela e daí de volta à imaginação materializada nos suvenires: 
Antes era preto e branco, mas pelo fato de hoje o Santa Marta ser uma das favelas mais coloridas do Rio de Janeiro, por ter esse projeto da Coral Tintas, hoje para a gente tudo tem cor, entendeu? Hoje nós, moradores do Santa Marta, já somos tudo de cor. Porque tudo leva cor. E uma coisa que chama a atenção dos turistas são as cores.

Na Figura 5, as seis primeiras telas exibem casas de traçado regular e delimitado por tinta preta, enquanto nas três últimas as cores ganham mais destaque que os próprios traços conformam numa representação mais abstrata da favela. Se nestas últimas telas as cores extrapolam as linhas que delimitam as residências e se juntam, formando um conjunto colorido com limites imprecisos que invadem a escadaria da favela, nas seis primeiras ganha realce um amontoado de casas em um morro cujo topo abriga a estátua do Cristo Redentor.

A presença da estátua evoca uma singularidade do Santa Marta: o fato de estar situado no coração da Zona Sul, converte-o, portanto, em mirante privilegiado a partir do qual é possível observar alguns dos principais pontos turísticos da "Cidade Maravilhosa". Note-se que, na sexta tela, o Pão de Açúcar também está presente no fundo da imagem. Mas, excetuando-se a estátua do Cristo que coroa o morro em algumas telas, a paisagem da favela que se reproduz nos quadros, camisetas e imãs vendidos no Santa Marta é quase sempre uma favela genérica, sem muitas características específicas do morro de Botafogo.

Morador do Santa Marta, artesão e guia de turismo, Barbosa nos conta que tem se questionado, ao longo dos últimos anos, sobre as estratégias de representação por ele empregadas em seus desenhos, ilustrações e pinturas. Diz que, inicialmente, pensava em identificar não apenas o Santa Marta, mas ainda outros morros em suas obras; a partir de uma reflexão atravessada por ambiguidades, porém, acabou chegando à representação de

uma favela descaracterizada. É uma favela. Não precisa identificar qual favela é. Meu primeiro projeto era retratar as favelas identificadas. Aqui é um produto do Santa Marta, primeira pacificada. Rocinha tem um traço de Niemeyer logo na entrada. Alemão tem um diferencial que é o bonde [teleférico]. Então, eu queria trabaIhar com isso. Mas ao mesmo tempo tem artistas nessas áreas, né? A minha etiqueta tem uma favela mais indefinida, você não consegue dizer se é no Rio ou em São Paulo. É só uma favela. Você reconhece que esses traços são de uma favela, mas não reconhece qual. [...] É uma coisa mais abstrata, mas a pessoa entende que é a ilustração de uma favela para respeitar justamente os artistas locais. Para que não seja só eu, mas que os outros também possam se dedicar. 


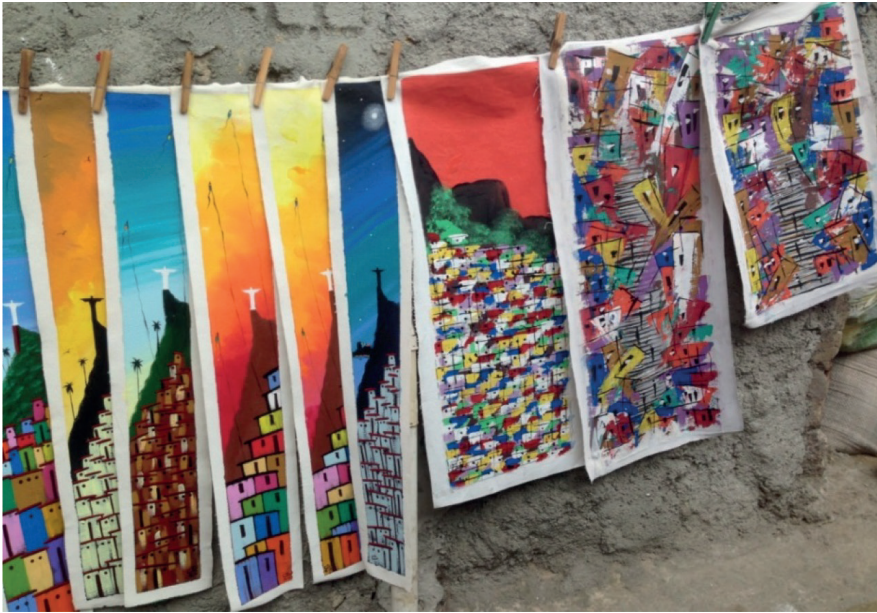

Figura 5: Telas expostas na frente de uma das lojas de souvenir do Santa Marta. Fonte: Palloma Menezes.

Para além do argumento de respeito aos artistas de cada favela - o que pressupõe, no discurso de Barbosa, não concorrer diretamente com estes -, tratar seu próprio lugar de moradia de um modo genérico, sem especificidades que o diferenciem dos outros morros, seria mais vantajoso por dois motivos principais. Por um lado, agrada os turistas, uma vez que os gringos parecem não se importar muito com o que é específico de cada uma, mas sim com o que seria típico das favelas de um modo geral. Por outro, o apelo à tipicidade e ao genérico permite também que esses pro-

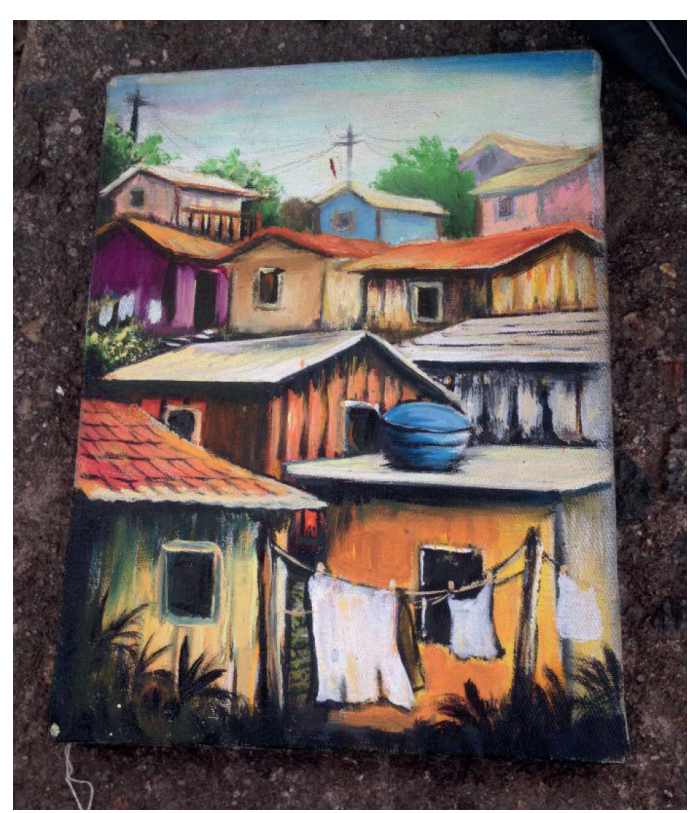

Figura 6: Crispim idealiza uma favela antiga e colorida. Fonte: Palloma Menezes. dutos circulem mais e sejam vendidos em outros espaços da cidade. Barbosa, por exemplo, a partir de uma parceria com a ONG Pipa Social, conseguiu lançar uma linha de cadernetas com seus desenhos da favela genérica (em modelos preto e branco ou colorido) que pode ser encontrada nas lojas de suvenir no Santa Marta, nas papelarias de grandes shoppings cariocas, nas lojinhas do Museu de Arte Moderna (MAM) e de outros museus.

O sucesso de venda das cadernetas, contudo, não foi suficiente para apaziguar Barbosa, que segue se questionando se não caberia a ele, como "cria do morro", produzir suvenires diferenciados para os turistas que visitam especificamente o Santa Marta: 
Marta? Então, minha ideia é criar um, dois ou três produtos com a cara do Santa Marta, com o bondinho, com as casas coloridas que a pessoa olha e sabe que é o Santa Marta.

Se, como argumentam Sheller e Urry (2004: 6), "lugares não são fixos nem dados, mas estão em jogo com relação a múltiplas mobilidades", as ponderações de Barbosa ajudam-nos a lembrar do quão inserido está o Santa Marta nos fluxos globais do turismo - para o bem e para o mal. Por um lado, essa inserção possibilita que a favela goze de uma visibilidade positivada; por outro, exige que seja domesticada e a despe de sua diversidade empírica.

Crispim, artista do Santa Marta, que pinta a favela em tacos de madeira e telas, aponta que busca inspiração para suas obras em lembranças do passado e em desejos projetados no tempo futuro. Seus quadros, mais do que retratar a realidade, expressariam seu desejo de uma transformação que está em progresso:

Eu almejo avançar e ir além da realidade que a gente está vivendo, pintar toda uma favela totalmente colorida. Quando a gente olha aqui de baixo, vê algumas casas coloridas, mas não é um colorido total e completo. [...] Nas minhas telas [busco] um sonho de favela que você possa olhar e se identificar com o belo [...], uma coisa harmoniosa, alegre, empolgante e agradável de ser vista.

No quadro representado na Figura 6, Crispim revela uma favela menos densa, com barracos de madeira rodeados por árvore a arbustos, e não sobrepostos uns aos outros como nas ilustrações anteriores. Só não cabe dizer que essa imagem retrata

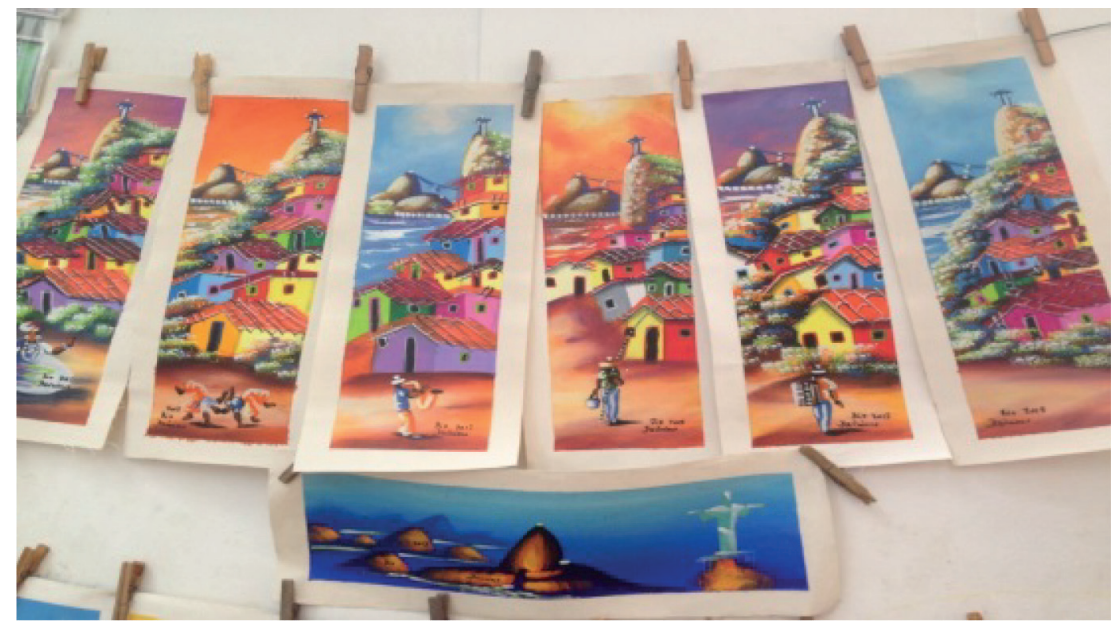

Figura 7: O elemento humano, retratado nas pinturas expostas em uma das lojas de souvenir do Santa Marta, corresponde, via de regra, à narrativa da tipicidade. Fonte: Palloma Menezes. 
fidedignamente o Santa Marta de algumas décadas porque na tela de Crispim as casas, mesmo sendo de madeira, aparecem pintadas de cores diversas e intensas. Segundo o artista, sua decisão em retratar a favela do passado tingida de cores justifica-se por dois motivos: por um lado, sempre morou em barraco e sempre sonhou que sua casa pudesse ser colorida como nas telas; por outro, acha que as cores são não apenas o elemento que mais chama a atenção do turista, mas aquele capaz de passar uma imagem positiva da favela ao olhar estrangeiro:

\begin{abstract}
$\mathrm{Na}$ verdade, eu morei em barraco. Eu posso dizer que eu ainda moro em um barraco. [...] E eu sempre sonhei em morar em um barraco colorido. E, por isso, acabei levando isso para as telas. $\mathrm{Na}$ verdade, até existiam [barracos coloridos], mas eram poucos. Hoje, se eu pudesse não viver na modernidade, eu faria uma casa no morro de madeira toda pintada. Se eu pudesse, eu ainda faria assim, como faço nas telas. Mas, por outro lado também, eu faço a cores porque para os turistas isso traz uma ideia não de tristeza e pobreza, mas de alegria.
\end{abstract}

É interessante notar que na tela de Crispim, assim como na maior parte das telas, camisas, canecas e imãs vendidos como suvenir no Santa Marta, a favela é quase sempre representada como um conjunto de casas, sem que os moradores estejam presentes. E, quando há algum elemento humano, raramente trata-se de um morador comum em atividades cotidianas. As personagens que habitam as telas são baianas, capoeiristas, músicos, sambistas etc., como podem ser vistos na Figura 7.

Mais uma vez, os produtores de suvenir justificam que representam esses personagens típicos porque antecipam ser o que os turistas desejam ver e consumir. Evocam igualmente o desejo de mostrar nos quadros uma favela alegre, com moradores que tocam instrumentos, com ginga, favelados que sambam, dançam e sabem, apesar de todas as adversidades, levar uma vida feliz. Nas palavras de Andreia, alguns quadros têm

capoeirista, têm o cara com sanfona porque tudo no morro é música, tudo aqui é motivo para sambar. É isso que o cara (turista) busca na favela!

\title{
Considerações finais:
}

a morte dos "antissuvenires"

A opção por pintar uma favela alegre e harmônica faz com que muitos dos problemas cotidianos enfrentados pelos moradores - falta de luz e água, saneamento e infraestrutura adequados, arbitrariedade policial - não sejam retratados nos suvenires. Como vimos aqui, os artistas justificam a ausência de aspectos negativos da 
vida do morro porque, por um lado, isso não interessaria aos turistas e, por outro, não seria essa a imagem de favela que desejam vender para o mundo. Crispim, por exemplo, afirma que evita retratar o "lado ruim" porque acha necessário usar sua arte para projetar aquilo de bom que deseja para um futuro próximo: "não retrato violência ou tristeza nos quadros porque acredito em um novo tempo".

E se algum artista se atrevesse a criar suvenires que mostrassem não só a beleza, mas também as malezas da vida na favela? Se nos suvenires os corpos negros não fossem retratados sambando ou jogando capoeira, mas sendo revistados por policiais militares? Se, nos cartões postais, em vez de casas coloridas tivéssemos as ruínas das casas das famílias que foram removidas? Se carros de brinquedo repletos de furos de bala e "caveirões" de pelúcia passassem a ser produzidos como representação do cotidiano nas favelas da "Cidade Maravilhosa"?

Ao subverter a lógica de que suvenires devem vender o que já existe de positivo ou projetar expectativas de um futuro desejado, um artista carioca gerou, às vésperas da Rio-2016, grande polêmica ao colocar à venda suvenires como os descritos acima. Rafucko ${ }^{10}$ apresentou tais produtos ao público no que ele chamou de "Monstruário 2016: a loja de antissuvenires do Rio de Janeiro para as Olimpíadas". Em um vídeo de lançamento da loja, o "artivista" exibiu e contextualizou os produtos que faziam parte da exposição inaugurada no Centro Cultural Hélio Oiticica:

Esses daqui são os cartões postais. [...] Um deles é o do apartheid, que são jovens negros sendo revistados em frente aos anéis olímpicos. E tem esse daqui que é uma foto da Vila Autódromo, uma comunidade removida forçadamente [...]. Vem com um pedacinho original de muro da Vila Autódromo. Esse daqui tá custando cinco reais, o outro é cortesia. A gente tem também as Havaianas customizadas com estampa de jovens negros sendo revistados na frente do ônibus a caminho da praia. Tá custando 30 reais. A gente tem o carrinho de brinquedo fuzilado pela PM do Rio de Janeiro. São 111 tiros e custa 111 reais. A gente tá vendendo também o livro Vencendo as adversidades. É a autobiografia da Deize Carvalho que é uma mãe que perdeu o filho morto e torturado no Degase ${ }^{11}$. Tem o quebra-cabeça Costa Barros [...] forma essa imagem [...] de carro fuzilado 111 vezes pela Polícia Militar. São 111 peças. Esse daqui é o item mais procurado: é a caneca do Beltrame. Tá custando 40 reais. [...] Aqui qualquer bebida fica intragável. E tem os mascotes de pelúcia para a criançada. [...] O Tratorzão, responsável pelas demolições e remoções ilegais. E o Caveirinho de pelúcia que é o caveirão, o carro do Bope ${ }^{12}$ que mata. Para finalizar, a gente tem também os pratos decorativos. Tem três estampas. Uma é o uniforme do Bope para conter as manifestações. A outra é o logotipo oficial do Bope. E uma comemorativa da ocupação do Exército na Maré. E tem o pano de prato do Globo que é uma capa do Jornal com [...] a nota
10. Rafucko é um artista e militante carioca que se autoidentifica como "bobo contemporâneo. Artivista multimídia. Freelancer como VJ, editor de vídeo, modelo e presença VIP em protestos". Atualmente, tem 84.800 seguidores no Facebook. Fonte: $<$ https://rafucko. com/bio/>. Acessado em abril de 2016 .

11. Departamento Geral de Ações Socioeducativas, órgão do governo estadual de execução das ações judiciais.

12. Batalhão de Operações Policiais Especiais do Rio de Janeiro. 
13. O Guerrilha (GRR) define-se como um coletivo de mídia independente que acredita na comunicação livre como instrumento de empoderamento e resistência.

14. Fonte: <http:// www.guerrilhagrr. com.br/sobre-a-dornegra-e-perifericacomo-souvenir-daesquerda-branca/> Acessado em abril de 2016. que saiu quando cinco meninos foram fuzilados pela polícia militar do Rio de Janeiro. O Mostruário 2016 está aberto até 21 de maio para visitação aqui no Centro Cultural Hélio Oiticica e a gente espera vocês virem conferir os antissuvenires que refletem a realidade do Rio de Janeiro.

Provavelmente Rafucko já esperava que o lançamento do Monstruário 2016 pudesse gerar rejeição entre os organizadores dos Jogos Olímpicos e entre representantes do poder público brasileiro ou, até mesmo, um estranhamento entre determinadas parcelas da população carioca. Mas o que o artista talvez não previsse era que sua arte seria duramente criticada por um grande número de moradores de favelas e militantes de direitos humanos. Robin Batista, estudante de Artes Visuais Afro-Diaspóricas, publicou um texto no blog do Coletivo Guerrilha $(G R R)^{13}$ criticando duramente a iniciativa de Rafucko:

Esses itens, símbolos de nossa tortura e terror diários, estão literalmente à venda como suvenires. Essa exposição transborda insensibilidade e mostra como a violência policial contra pretos e pobres virou uma carta discursiva escondida na manga dessa esquerda branca, um verdadeiro produto, em todos os sentidos. ${ }^{14}$

O texto de Robin, além de questionar o "lugar de fala" de Rafucko - homem branco de classe média falando em nome dos negros e favelados -, explicitou algo que, até então, havia passado despercebido para muitas pessoas: os chamados antissuvenires não só faziam parte de uma performance, mas estavam sendo de fato vendidos. Diante de uma comercialização que Ihes parecia imoral, moradores de favelas e militantes organizaram um ato de repúdio à Expo Monstruário. No evento criado no Facebook para divulgar o ato era dito que:

Rafucko, o Luciano Huck da esquerda, [...] apresenta suvenires que estão à venda (Sim! À venda). Não podemos admitir que nossa dor seja exposta de forma pejorativa, além de utilizada para promover um homem branco que já tem um histórico ruim ao falar de questões que dizem respeito a nós, se diz de esquerda, mas não nos lê e não quer saber o que pensamos. A exposição é macabra, de muito mau gosto, e explora a dor de um povo [...].

Para tentar se defender das acusações de que estaria lucrando com a venda da dor alheia, Rafucko divulgou uma carta aberta direcionada, especialmente, às famílias afetadas pela violência policial no Rio de Janeiro. No texto, além de fazer uma autocrítica, defendeu a comercialização dos antissuvenires:

[...] A venda é parte importante da obra, por reproduzir/revelar essa lógica comercial e monstruosa que transforma a cidade 
num parque temático pra poucos enquanto a juventude negra é chacinada. É importante dizer que apesar de os produtos serem vendidos, não houve lucro [...]. A venda, feita num espaço da Prefeitura, é também uma crítica a como o Estado insiste em vender a cidade do Rio de Janeiro como maravilhosa, mesmo em meio a tanto sangue e tantas dores. Usei o logotipo oficial das Olimpíadas para deixar claro que a memória que se deve levar deste evento é também aquela dos que foram excluídos da grande festa, seja pela remoção de sua casa ou de suas vidas e de entes e amigos queridos.

Na parte final da carta, Rafucko destaca que sua intenção era denunciar a dinâmica naturalizada da violência promovida pelo Estado. Mas, como a discussão tomou outro viés, ele resolveu tirar seus objetos de exposição e substituí-los por suvenires oficiais da cidade do Rio. Ainda assim, disse que seguiria chamando a exposição de "Monstruário" porque a ideia da exposição permaneceria a mesma: ser "uma vitrine que pretende esconder as monstruosidades praticadas pelo Estado contra a população".

Para além de qualquer apreciação moral ou estética que se possa fazer dos produtos de Rafucko, fato é que as polêmicas em torno de sua iniciativa explicitam e resumem de forma contundente um argumento que atravessa este artigo: é fundamental manter uma perspectiva histórica na abordagem do tema "favela turística". Somente o recuo no tempo permite compreender a polêmica em torno das peças de Rafucko sem que se recorra, por exemplo, à polarização entre representações "de dentro" e "de fora". Não há qualquer novidade no fato de a favela ser apropriada como elemento de representação artística por um sujeito que the é alheio - ao contrário: é bastante extensa a lista de pintores, literatos, poetas, músicos que, moradores de outras partes da cidade ou mesmo estrangeiros, a tomaram como tema. A favela "colorida", bucólica e de uma ruralidade atávica, muito antes de habitar as telas dos artistas que residem na Rocinha e no Santa Marta, se fez presente, por exemplo, nos reverenciados quadros de Tarsila do Amaral ("Morro da favella", 1924) e Di Cavalcante ("Favela", 1958).

Essa perspectiva temporal nos habilita, ainda, problematizar a "arte nativa" como portadora de uma autenticidade imaculada, alheia a essas outras obras consagradas cujos princípios de representação encontram-se sedimentados em um imaginário compartilhado sobre as favelas. Nesse sentido, as ansiedades explicitadas nas falas dos artistas locais que reproduzimos aqui podem ser entendidas como decorrentes não apenas de seu compromisso com interesses mercadológicos, mas também das pressões que determinadas convenções pictóricas, consagradas pela história oficial da arte brasileira, Ihes impõem ${ }^{15}$.

15. Agradecemos a(o) parecerista anônima(o) a sinalização das tensões e continuidades entre a representação da favela feita pelos moradores e aquela consagrada pela história da arte oficial. 
Diante da polêmica gerada pelos antissuvenires, cabe ainda indagar: aos objetos que estão encarregados de tornar tangível a experiência da favela turística é permitido ou não revelar as dinâmicas violentas e as dores que fazem parte da vida cotidiana de quem habita as margens da cidade? Estariam os objetos produzidos para consumo turístico fadados a viajar o mundo levando somente lembranças positivas dos destinos? Ou será que também podem carregar representações que não estejam descoladas da realidade e dos problemas cotidianos muitas vezes invisíveis aos turistas, mas vivenciados pelos moradores? Suvenires podem servir como dispositivos de luta política ajudando a divulgar internacionalmente o que a propaganda oficial dos destinos turísticos tende a apagar? Ao trazer a produção de "lembranças" do Rio como epicentro do debate sobre representações da favela e da cidade, buscamos não só mapear como e por quem os suvenires são produzidos, mas analisar também alguns dos dilemas envolvidos na materialização e transformação da desigualdade, exclusão social, racismo e violência estatal em mercadorias. O caso dos suvenires - e dos antissuvenires - força-nos a pensar sobre os limites morais intrínsecos à comercialização da dor do outro, mesmo quando a intenção seria denunciar os responsáveis pela dor causada. Será que existe uma forma ética e moralmente aceitável de comercializar a dor alheia?

Abstract: This article examines the biography of the touristic favela in reference to its material culture. Souvenirs produced and sold in two Rio de Janeiro favelas, Rocinha and Santa Marta, are the focus of observation, aiming to understand spirals of meaning created in the confluence between imagination and materiality, art and topography. We begin with the colors that are born on canvas painted for the consumption of tourists and are reproduced on the walls of the favelas, understanding them as the spawn of poltics based on new visibility regimes and poverty control. Final remarks reflect on the death of (anti)souvenirs, or what appears to be the lack of further possibilities for the representation of favelas as a brand which is capable of adding value to different products on the global market.

Keywords: souvenir, favela, tourism, material culture, megaevents.

\section{Referências}

APPADURAI, Arjun. The social life of things: comrnodities in cultural perspective. Cambridge: Cambridge University Press, 1986.

BOLTANSKI, Luc; CHIAPELLO, Ève. The new spirit of capitalism. London; New York: Verso, 2005.

CAVALCANTI, Mariana. À espera, em ruínas: urbanismo, estética e política no Rio de Janeiro da PACificação. Dilemas: Revista de Estudos de Conflito e Controle Social, v. 6, p. 191-228, 2013. 
CLARKE, Terry (Org.). The city as an entertainment machine. Chicago: University of Chicago; Elsevier, 2003.

FOUCAUL, Michel. Vigiar e punir. Nascimento da prisão. 8. ed. Petrópolis: Vozes, 1991.

FREIRE-MEDEIROS, Bianca. Touring poverty. "Advances in Sociology" series. Londres; New York: Routledge, 2013. v. 1.

. Felicidade é... uma favela violenta com vista para o mar. In: FREIRE FILHO, João (Org.). Ser feliz hoje: reflexões sobre o imperativo da felicidade, p. 257-273. Rio de Janeiro: FGV, 2010.

- Gringo na laje: produção, circulação e consumo da favela turística. Rio de Janeiro: FGV Editora, 2009.

A favela que se vê e que se vende: reflexões e polêmicas em torno de um destino turístico. Revista Brasileira de Ciências Sociais (impresso), v. 22, p. 61-72, 2007.

FREIRE-MEDEIROS, Bianca; VILAROUCA, Marcio Grijó; MENEZES, Palloma Valle. A pobreza turística no mercado de pacificação: reflexões a partir da experiência da Favela Santa Marta. Salvador: CRH, 2016.

FREIRE-MEDEIROS, Bianca; VILAROUCA, Marcio Grijó. Would you be a favela tourist? Confronting expectations and moral concerns among brazilian and foreign potential tourists. In: DIEKMANN, Anya; SMITH, Melanie Kay (Orgs.). Ethnic and minority cultures as tourist attractions, p. 151-168. Bristol: Channel View Publications, 2015.

FREIRE-MEDEIROS, Bianca; VILAROUCA, Marcio Grijó; MENEZES, Palloma Valle. International tourists in a "pacified" favela: profiles and attitudes. The case of Santa Marta, Rio de Janeiro. Die Erde, v. 144, p. 147-159, Berlin, 2013.

FREIRE-MEDEIROS, Bianca; NUNES, Fernanda; MENEZES, Palloma Valle. Ética, estética e consumos possíveis: Notas etnográficas sobre turismo em uma favela carioca. Os Urbanitas, v. 5, p. 3, São Paulo, 2008.

FRENZEL, Fabian. Slumming it. London: Zed Books, 2016.

FRENZEL, Fabian; KOENS, Ko; STEINBRICNK, Malte. Introduction. In: FRENZEL, Fabian; KOENS, Ko; STEINBRICNK, Malte (Eds.). Slum tourism poverty, power and ethics. London: Routledge, 2012.

GORDON, Beverly. The souvenir: messenger of the extraordinary. Journal of Popular Culture, v. 20, n. 3, p. 135-146, 1986. 
HALNON, Karen. Poor chic: the rational consumption of poverty. Current Sociology, v. 50, n. 4, p. 501-516, Jul. 2002.

KIM, Soyoung; LITTRELL, Mary A. Souvenir buying intentions for self versus others. Annals of Tourism Research, v. 28, n. 3, p. 638-657, 2001.

LEITE, Márcia Pereira. De territórios da pobreza a territórios de negócios: dispositivos de gestão das favelas cariocas em contexto de "pacificação". In: BIRMAN, Patrícia; LEITE, Márcia Pereira; MACHADO, Carly; CARNEIRO, Sandra de Sá (Orgs.). Dispositivos urbanos e trama dos viventes: ordens e resistências, p. 377-401. Rio de Janeiro: FGV Editora, 2015, v. 1.

MENEZES, Palloma Valle. Objeto e sujeito da fotografia: gringos e câmeras na favela da Rocinha. Cadernos de Antropologia e Imagem (UERJ), v. 25, p. 65-78, 2007.

MORAES, Camila. O turismo em favela em debate. Revista Plural (USP), no prelo.

NUNES, Fernanda. As representações da favela e seus significados: o caso dos souvenires "by Rocinha". In: PANOSSO NETTO, Alexandre; GAETA, Cecília (Orgs.). Turismo de experiência. São Paulo: Editora Senac, 2010.

SHELLER, M.; URRY, J. The new mobilities paradigm. Environment and Planning A, v. 38, p. 207-226, 2006.

- (Eds.). Tourism mobilities: places to play, places in play. London: Routledge, 2004.

SWANSON, Kristen. Tourists' and retailers' perceptions of souvenirs. Journal of Vacation Marketing, v. 10, p. 363-377, London: Sage 2004.

TEIXEIRA, Ib. O fantástico colapso do turismo no Brasil. Revista Conjuntura Econômica, v. 50, n. 1, p. 42-43, Rio de Janeiro, Maio 2015. Disponível em: <http://bibliotecadigital.fgv.br/ojs/index.php/rce/article/view/49125>. Acesso em: 26 Nov. 2016.

TELLES, Vera da Silva. Cidade: produção de espaços, formas de controle e conflitos. Revista de Ciências Sociais (UFC), v. 46, p. 15-42, 2015.

URRY, John. Mobilities. Cambridge: Polity, 2007.

_ Globalising the tourist gaze. Lancaster: Lancaster University, 2001.

- The tourist gaze. London: Sage, 1990.

WARD, Cheryl B.; TRAN, Thuhang. Consumer gifting behaviors: one for you, one for me?, Services Marketing Quarterly, v. 29, n. 2, p. 1-17, 2007. 